\title{
PENDEKATAN METODE NAÏVE BAYES CLASSIFIER UNTUK MEMPREDIKSI KEMAMPUAN DELAY OF GRATIFICATION ANAK DENGAN DOWN SYNDROME
}

\author{
Neneng Tati Sumiati ${ }^{1}$, Frieda Mangunsong ${ }^{2}$, dan Guritnaningsih ${ }^{3}$ \\ ${ }_{1,2,3}$ Universitas Indonesia, \\ Jalan Margonda Raya, Kota Depok, Jawa Barat 164242 \\ ${ }^{1}$ Universitas Islam Negeri Syarif Hidayatullah Jakarta \\ Jalan Kertamukti No. 5, Cireundeu, Ciputat, Tangerang Selatan, 15419 \\ E-mail: ntatisumiati@gmail.com
}

\begin{abstract}
ABSTRAK
Kemampuan delay of gratification merupakan hal mendasar untuk dapat menampilkan perilaku goal-directed dan memprediksi perkembangan kognitif dan sosial. Kemampuan delay of gratification diharapkan menjadi perilaku yang relatif stabil, sementara hasil penelitian menunjukkan kemampuan delay of gratification pada anak dengan Down Syndrome (DS) rendah dan tidak konsisten. Penelitian ini bertujuan untuk memprediksi kemampuan delay of gratification melalui metode Naïve Bayes Classifier (NBC). Partisipan penelitian ini berjumlah 28 anak dengan DS usia kronologis 7 sampai 14 tahun, usia mental minimal 24 bulan, kecerdasan berada pada tingkat moderat, dan berdomisili di Jakarta. Alat ukur yang digunakan adalah tugas delay dan kuesioner delay of gratification. Hasil penelitian menunjukkan bahwa kemampuan delay of gratification anak dengan DS yang diukur melalui tugas delay dapat memprediksi kemampuan delay of gratification domain makanan, physical pleasure, dan interaksi sosial dengan tingkat akurasi sebesar $71.43 \%$.
\end{abstract}

Kata kunci: Delay of gratification; Down Syndrome; Nä̈ve Bayes Classffier

\section{THE APPROACH OF NAÏVE BAYES CLASSIFIER METHOD TO PREDICT DELAY OF GRATIFICATION ABILITY IN CHILDREN WITH DOWN SYNDROME}

\begin{abstract}
The delay of gratification ability is fundamental to being able to display goal-directed behavior and predict cognitive and social development. The delay of gratification ability would be expected to be a relatively stable behavior, while study results show that the delay of gratification ability in children with Down Syndrome (DS) is low and inconsistent. This study aims to predict the delay of gratification ability through the Naïve Bayes Classifier (NBC) method. Participants in this study were 28 children with DS chronological age 7 to 14 years, minimum mental age 24 months, intelligence at a moderate level, and residing in Jakarta. The measuring instrument used is the delay task and the delay of gratification questionnaire. Data were analyzed using the NBC method. The results showed that the delay of gratification ability of children with DS as measured by the delay task can predict the delay of gratification ability in the food domain, physical pleasure, and social interaction with an accuracy level of $71.43 \%$.
\end{abstract}

Keyword: Delay of gratification; Down Syndrome; Naïve Bayes Classifier 
Neneng Tati Sumiati, Frieda Mangunsong, Guritnaningsih | 67

Pendekatan Metode Naïve Bayes Classifier untuk Memprediksi Kemampuan Delay of Gratification Anak dengan Down Syndrome

\section{PENDAHULUAN}

Kemampuan delay of gratification merupakan hal mendasar dalam mengarahkan perilaku bertujuan yang kompleks (Mischel, 1974; Cuskelly, Zhang \& Gilmore, 1998). Individu harus belajar untuk menunggu hasil yang diinginkan dan menangguhkan dorongan untuk segera mendapatkan kepuasan (Mischel, 1974; Liu, Wang, \& Jiang, 2013). Delay of gratification merupakan kapasitas individu untuk melawan dorongan untuk mendapatkan reward secara langsung dan menunggu reward yang lebih besar di masa depan (Ho, Tong, \& Jia, 2016).

Mischel (1974) mengemukakan bahwa delay of gratification terdiri dari dua tahap. Tahap pertama adalah menentukan pilihan untuk menunggu dan tahap kedua adalah berkenaan dengan kemampuan untuk tetap bertahan secara terus menerus hingga sampai pada tujuan akhir yang dipilih (Mischel, 1974). Delayer adalah individu yang dapat menunda keinginannya agar mendapatkan reward yang lebih berharga, sementara non-delayer adalah individu yang tidak dapat menunda keinginannya.

Konsep tentang dua tahap dari delay of gratification ini dibuktikan dalam penelitian Liu et al. (2013). Temuan Liu et al. (2013) menunjukkan bahwa delay of gratification memiliki dua dimensi, yaitu dimensi controlling-impulse dan planning-and-waiting. Controlling impulses fokus pada delayer membuat pilihan untuk meninggalkan immediate gratification, sedangkan planning-and-waiting berfokus pada motivasi delayer untuk menunggu hadiah yang lebih berharga di masa depan (Liu et al., 2013). Dimensi tersebut selaras dengan tahapan delay of gratification yang dikemukakan oleh Mischel (1974). Controlling-impulse setara dengan tahap satu, yaitu menentukan pilihan untuk menunggu, sementara planning-and-waiting setara dengan tahap dua, yaitu kemampuan terus menerus untuk tetap bertahan menungggu pada tujuan akhir yang dipilih.

Hasil penelitian menunjukkan bahwa delay of gratification berhubungan dengan kompetensi kognitif dan sosial, kinerja skolastik, serta kemampuan mengatasi frustrasi dan stres (Mischel et al., 1989). Anak-anak yang memiliki kemampuan delay of gratification yang tinggi dapat menampilkan perilaku regulasi diri yang baik (Mischel et al., 1989). Anak-anak yang kurang mampu melakukan delay of gratification memiliki masalah-masalah perilaku, adaptasi, dan masalah terkait prestasi di berbagai bidang (Dansereau, Knight, \& Flynn, 2013). Mischel (1974) berpendapat bahwa kemampuan delay of gratification ini diperlukan untuk dapat mengikuti aturan yang terdapat dalam sistem sosial budaya.

Anak dengan down syndrome (selanjutnya disingkat DS) merupakan anak-anak yang memiliki kelainan kromosom, yaitu terdapat ekstra kromosom pada kromosom ke-21 yang diduga menyebabkan disabilitas intelektual (Sastre-Riba, Fonseca-Pedrero, \& Poch-Olivé, 2015; Roubertoux \& Kerdelhue, 2006). Mereka memiliki keterbatasan dalam kemampuan memori dan bahasa, terutama bahasa ekspresif (Lott \& Dierssen, 2010; Finestack, \& Abbeduto, 2010; Carney, Henry, et al., 2013). Anak dengan DS juga memiliki masalah emosi dan perilaku yang lebih banyak dibandingkan individu nondisabilitas (Gameren-Oosterom, Fekkes, Buitendijk, Mohangoo, \& Wouwe, 2011). Salah satu masalah perilaku mereka adalah kemampuan regulasi diri yang rendah (Saldaña, 2004; Gilmore, Cuskelly \& Hayes, 2003).

Hasil penelitian pada anak dengan DS menunjukkan bahwa anak dengan DS memiliki kemampuan delay of gratification yang rendah dibandingkan anak nondisabilitas yang memiliki usia mental yang setara ataupun dengan anak dengan disabilitas intelektual etiologi lainnya (Kopp, 1990; Gilmore et al., 2003; Cuskelly et al., 2003; Cuskelly et al., 2016). Beberapa penelitian menunjukkan bahwa rendahnya kemampuan delay of gratification pada anak dengan DS berkorelasi dengan kemampuan bahasa yang rendah dan usia mental mereka yang berada jauh di bawah usia kronologisnya (Cuskelly et al., 2001; 2003; 2016). Kemungkinan lain disebabkan adanya neurological atypicalities yang dialami anak dengan DS khususnya pada lobus frontalis dan hipokampus (Lott \& Dierssen, 2010; Pinter et al., 2001) yang bertanggung jawab terhadap kontrol perilaku dan regulasi emosi (Zelazo, 2015). Anak dengan DS memiliki kemampuan inhibitory control yang rendah (Borella et al., 2013; Brunamonti et al., 2011; Costanzo et al., 2013; Lanfranchi et al., 2010; Rowe et al., 2006), mengalami kesulitan dalam melakukan regulasi diri (Gilmore, Cuskelly, \& Hayes, 2003), serta seringkali menampilkan perilaku externalizing behavior, seperti hiperaktivitas, impulsif, dan keras kepala (Grieco et al., 2015). Menurut Hoerger, Quick, \&Weed (2011), kemampuan delay of gratification berhubungan dengan externalizing behavior. Individu yang memiliki kemampuan delay of gratification yang rendah lebih banyak memiliki masalah externalizing behavior. 
Neneng Tati Sumiati, Frieda Mangunsong, Guritnaningsih |

Pendekatan Metode Naïve Bayes Classifier untuk Memprediksi Kemampuan Delay of Gratification

Anak dengan Down Syndrome

Penelitian Kopp (1990) tentang delay of gratification pada anak dengan DS diukur melalui dua tugas delay. Pada tugas pertama, anak diminta peneliti untuk tidak menyentuh telepon yang menarik dan tugas kedua, di mana peneliti menyembunyikan sebuah kismis di bawah cangkir, pada tugas kedua inipun anak diminta untuk menunggu sebelum mencari kismis tersebut. Kedua tugas ini merupakan other-directed waiting tasks. Hasilnya menunjukkan bahwa tidak ada korelasi antara waiting time kedua tugas tersebut. Sementara itu, diketahui bahwa terdapat korelasi sebesar 0.71 pada anak nondisabilitas dengan usia mental yang setara.

Cuskelly dan koleganya (2001) mengukur kemampuan delay of gratification melalui dua tugas delay. Tugas delay pertama, mengadaptasi tugas delay yang dilakukan Mischel (1974), yaitu anak diminta memilih sebuah makanan sekarang atau dua makanan tapi harus menunggu beberapa waktu. Pada tugas kedua, anak diminta menentukan pilihan majalah yang diinginkannya. Anak dapat memperoleh dua majalah bila bersedia menunggu, namun hanya mendapat satu majalah saja bila tidak menunggu. Kedua tugas ini merupakan selfimposed delay of gratification task. Hasil penelitian menunjukkan adanya korelasi waiting time pada kedua tugas tersebut.

Cuskelly et al. (2003) mengukur kemampuan delay of gratification anak dengan DS melalui tiga tugas delay, yaitu tea-task, gift-task, dan self-imposed delay of gratification task. Tea-task adalah tugas delay di mana anak dihadapkan dengan makanan kesukaan dan makanan lainnya dan ibu meminta anak untuk tidak menyentuh makanan tersebut sampai diizinkan. Gift-task adalah tugas delay di mana anak ditunjukkan sebuah kado yang terbungkus dengan bagus dan anak diberitahu bahwa kado tersebut boleh menjadi miliknya bila ia bersedia menunggu. Self-imposed adalah tugas delay di mana anak diminta untuk memilih mainan yang diinginkannya kemudian anak diminta menunggu untuk mendapatkan mainan yang diinginkannya. Hasilnya adalah tidak ada korelasi antara waiting time pada self-imposed delay of gratification task dengan tea-task maupun gift-task. Namun, terdapat korelasi antara waiting time pada tea-task dan waiting time pada gift-task. Tugas delay tea-task dan gift-task merupakan tugas delay yang termasuk other-directed.

Temuan tentang kemampuan delay of gratification pada anak dengan DS pada penelitian sebelumnya (Kopp, 1990; Cuskelly et al., 2001; Cuskelly et al., 2003) menunjukkan hasil yang berbeda pada other-directed maupun self-imposed delay of gratification tasks. Ketidakkonsistenan kemampuan delay of gratification pada anak DS yang terukur melalui tugas-tugas delay yang berbeda mungkin disebabkan oleh karakteristik dari tugas delay tersebut. Misalnya pada tea task, anak DS dihadapkan dengan makanan favorit mereka, padahal hasil penelitian Dykens, Schwenk, Maxwell, dan Myatt (2007) menunjukkan bahwa anak dengan DS memiliki ketertarikan yang besar dalam domain makanan. Kemungkinan lain berkaitan dengan karakteristik anak dengan DS, seperti orientasi sosial yang kuat. Anak dengan DS senang berinteraksi dan beraktivitas dengan orang lain (Kasari \& Freeman, 2001). Hal ini mungkin menyebabkan anak dengan DS mengalami kesulitan saat menjalankan tugas delay of gratification dalam situasi penelitian, di mana mereka berada sendirian di ruangan eksperimen (Cuskelly et al., 2003). Kondisi ini mungkin terjadi pula dalam situasi sehari-hari, di mana anak dengan DS dapat menunda keinginannya dalam satu domain, namun tidak dapat menunda pada domain lainnya. Bagaimanapun juga, hal tersebut masih memerlukan pembuktian.

Hoerger et al. (2011) mengungkapkan bahwa delay of gratification memiliki lima domain, yaitu domain makanan, physical pleasure, interaksi sosial, uang, dan achievement. Mereka mengukur kelima domain ini melalui kuesioner. Hanya saja, penelitian Hoerger et al. (2011) dilakukan pada orang dewasa nondisabilitas sehingga alat ukur ini tidak cocok untuk mengukur kemampuan delay of gratification pada anak dengan DS. Adapun domain yang masih memungkinkan dapat diukur pada anak dengan DS adalah domain makanan, physical pleasure, dan interaksi sosial.

Hasil penelitian sebelumnya menunjukkan bahwa pengukuran kemampuan delay of gratification pada anak dengan DS dilakukan dengan tugas delay, baik self-imposed delay of gratification maupun other-directed waiting tasks, sehingga belum terdapat teknik pengukuran lain, seperti kuesioner. Padahal, kuesioner dapat digunakan untuk mengungkapkan beberapa domain delay of gratification sekaligus. Pada anak dengan DS, penggunaan kuesioner yang diisi orang tua mungkin dapat mengungkapkan kemampuan delay of gratification pada aktivitas sehari-hari sehingga karakteristik tugas delay yang mungkin memengaruhi performa kemampuan delay of gratification pada anak dengan DS pun dapat teratasi. Selain itu, diharapkan penggunaan 
Neneng Tati Sumiati, Frieda Mangunsong, Guritnaningsih |

kuesioner dapat membantu dalam mendapatkan informasi tentang kemampuan delay of gratification anak dengan DS pada beberapa domain dan konsistensinya.

Mempertimbangkan penelitian sebelumnya, penelitian saat ini difokuskan untuk menelaah konsistensi kemampuan delay of gratification anak dengan DS melalui waiting time pada tugas delay dengan kemampuan delay of gratification pada domain makanan, physical pleasure, dan interaksi sosial. Temuan pada penelitian ini diharapkan dapat memfasilitasi proses identifikasi dan evaluasi kemampuan delay of gratification pada anak dengan DS sehingga mereka dapat mengelola dan mengarahkan perilaku mereka sendiri tanpa banyak mengandalkan arahan dari lingkungan.

Penelitian yang telah dilakukan berkenaan dengan konsistensi kemampuan delay of gratification menggunakan metode korelasional (Kopp, 1990; Cuskelly et al., 2001; Cuskelly et al., 2003). Metode korelasional merupakan suatu metode yang melihat keterkaitan satu variabel dengan variabel lainnya sehingga dapat diketahui kekuatan dan arah hubungan kedua variabel tersebut (Goodwin, 2010). Namun, metode korelasi tidak menunjukkan hubungan fungsional dari korelasi kedua variabel tersebut, seperti pada metode Naïve Bayes Classifier (NBC) (Muktamar, Setiawan \& Adji, 2015). Sementara itu, metode NBC dapat memprediksi probabilitas di masa depan berdasarkan pengalaman sebelumnya.

Penelitian ini berfokus untuk menelaah probabilitas kemampuan delay of gratification anak dengan DS pada tugas delay, dengan kemampuan delay of gratification pada domain makanan, physical pleasure, dan interaksi sosial menggunakan metode NBC. Metode NBC adalah istilah dalam statistik Bayes yang berkenaan dengan klasifikasi probabilistik sederhana berdasarkan penerapan teorema Bayes dengan asumsi independensi yang kuat (naif) (Bhargavi, \& Jyothi, 2009). Kelebihan dari metode NBC adalah sederhana, yaitu menggunakan klasifikasi probabilistik dari data, namun memiliki tingkat akurasi yang tinggi dan error rate yang rendah (Setiawan, Astuti, Kridalaksana, 2015).

Pada penelitian ini, metode NBC digunakan untuk membuktikan klasifikasi anak dengan DS yang tergolong delayer dan non-delayer, berdasarkan waiting time saat menjalankan tugas delay, secara akurat sesuai dengan kemampuan delay of gratification domain makanan, physical pleasure, maupun interaksi sosial yang dilaporkan oleh ibu. Selain untuk membuktikan tingkat akurasi, penelitian ini juga ditujukan untuk membuktikan tingkat sensitivitas dan spesifisitas dari pengukuran delay of gratification pada anak dengan DS. Sensitivitas adalah jumlah anak dengan DS yang terklasifikasi non-delayer pada tugas delay terbukti benar non-delayer pada domain makanan, physical pleasure, dan interaksi sosial. Sebaliknya, tingkat spesifisitas adalah jumlah anak dengan DS yang terklasifikasi delayer pada tugas delay terbukti benar delayer pada domain makanan, physical pleasure, dan interaksi sosial. Dengan kata lain penelitian ini bertujuan untuk membuktikan tingkat akurasi, sensitivitas, dam spesifisitas dari pengukuran kemampuan delay of gratification pada anak dengan DS.

\section{METODE}

Penelitian ini menggunakan rancangan noneksperimental karena penelitian ini ditujukan untuk menggambarkan suatu hubungan antarvariabel, tetapi tidak menjelaskan hubungan sebab-akibat (Gravetter, 2018). Penelitian ini bertujuan untuk membuktikan bahwa kemampuan delay of gratification yang diukur melalui waiting time pada saat menjalankan tugas delay dapat memprediksi kemampuan delay of gratification yang diukur melalui kuesioner pada domain makanan, physical pleasure, dan interaksi sosial pada anak dengan DS.

Partisipan pada penelitian ini adalah anak dengan DS yang memiliki usia kronologis 7 hingga 14 tahun, usia mental minimal 24 bulan, kecerdasan berada pada taraf moderat agar mereka dapat memahami tugas delay (Cournoyer \& Truder, 1991), memiliki penglihatan dan pendengaran yang normal agar mereka dapat melihat reward yang ditawarkan dan mendengar instruksi tentang tugas delay, serta berdomisili di Jakarta untuk memudahkan pengambilan data. Sebanyak 32 anak dengan DS di mana orang tuanya mengizinkan anaknya mengikuti penelitian, namun hanya 28 anak dengan DS yang datanya valid untuk dianalisis.

Proses penelitian terdiri dari dua tahap, yaitu tahap persiapan dan tahap pengambilan data. Tahap persiapan adalah tahap penyusunan kuesioner delay of gratification domain makanan, physical pleasure, dan 
Pendekatan Metode Naïve Bayes Classifier untuk Memprediksi Kemampuan Delay of Gratification

Anak dengan Down Syndrome

interaksi sosial. Tahap pengambilan data dilakukan setelah lolos kelayakan etik dari Komisi Etik Fakultas Psikologi Universitas Indonesia dan mendapatkan informed consent dari orang tua anak dengan DS.

Proses penyusunan kuesioner delay of gratification diawali dengan studi literatur tentang kemampuan delay of gratification pada anak dengan DS yang mencakup pengukurannya. Kuesioner yang disusun terdiri dari domain makanan, physical pleasure, dan interaksi sosial (Hoerger et al., 2011) dengan menggunakan dimensi controlling-impulse dan planning-and-waiting (Liu et al., 2013). Review (validasi isi) terhadap kuesioner yang telah disusun dilakukan oleh enam orang ahli pada bidang yang terkait, yakni bidang anak berkebutuhan khusus, perkembangan, pendidikan, dan riset. Langkah berikutnya adalah melakukan revisi terhadap kuesioner sesuai dengan masukan dari para ahli tersebut. Kemudian, kuesioner yang direvisi tersebut diujicobakan pada beberapa orang tua anak dengan DS dengan tujuan sebagai uji keterbacaan. Kuesioner yang telah direvisi terdiri dari 14 butir soal. Tabel 1 menampilkan blue print dari kuesioner delay of gratification.

Tabel 1. Blue Print Kuesioner Delay of Gratification

\begin{tabular}{cccc}
\hline Domain & \multicolumn{2}{c}{ Dimensi } & Jumlah \\
\cline { 2 - 3 } & Control-impulse & $\begin{array}{c}\text { Planning-and- } \\
\text { waiting }\end{array}$ & \\
\hline Makanan & 1,3 & 2,4 & 4 \\
Physical pleasure & $5,7,9$ & $6,8,10$ & 6 \\
Interaksi sosial & 11,13 & 12,14 & 4 \\
\hline Jumlah & 7 & 7 & 14 \\
\hline
\end{tabular}

Setiap butir soal terdiri dari tiga alternatif pilihan jawaban, yaitu satu pilihan jawaban yang bersifat favorable dan dua pilihan jawaban yang unfavorable. Pilihan jawaban favorable diberi skor satu dan pilihan jawaban unfavorable diberi skor nol sehingga jumlah skor total terentang dari nol hingga 14. Pilihan jawaban favorable mencerminkan perilaku delay of gratification, sebaliknya unfavorable memperlihatkan perilaku yang tidak dapat menunda gratifikasi. Hasil uji validitas kuesioner delay of gratification menunjukkan bahwa seluruh butir soal valid dengan dengan nilai $\mathrm{r}_{\mathrm{it}}=0,352$ sampai dengan 0,686 dan nilai reliabilitas 0,81.

Alat ukur yang digunakan pada penelitian ini adalah tes kecerdasan Stanford-Binet, kuesioner delay of gratification, dan tugas delay. Tes kecerdasan Stanford-Binet digunakan untuk menjaring partisipan berkenaan dengan taraf kecerdasan dan usia mental. Tes Stanford-Binet ini dilakukan secara individual oleh psikolog. Tugas delay digunakan untuk mengukur kemampuan delay of gratification anak dengan DS melalui pemberian tugas. Tugas delay ini memodifikasi tugas delay yang telah dikembangkan oleh Mischel (1974) serta Cuskelly et al. $(2001 ; 2003 ; 2016)$, yaitu meminta anak memilih satu di antara dua kado yang ditawarkan, di mana satu kado kecil yang dibungkus kertas coklat dan satu lagi kado dengan ukuran yang besar dan dibungkus kertas kado yang bagus. Setelah menentukan pilihan, anak diminta menunggu kado yang dipilih di ruangan dan di hadapannya terdapat kado yang tidak dipilih. Kado yang dipilih dibawa oleh eksperimenter keluar ruangan. Apabila anak berhasil menunggu kado yang dipilih selama 15 menit (900 detik) tanpa menyentuh atau merusak kado yang tidak pilih, anak akan mendapatkan kado yang dipilihnya tersebut. Sebaliknya, apabila anak menyentuh atau merusak kado yang ada dihadapannya, anak hanya mendapatkan kado yang ada di hadapannya tersebut dan tidak mendapatkan kado yang dipilihnya. Selama menunggu, anak berada di ruangan sendirian bersama kado yang tidak dipilihnya. Kemampuan delay of gratification diukur dengan lamanya waktu menunggu (waiting time) yang dimulai sejak eksperimenter meninggalkan ruangan hingga anak menyentuh atau merobek kado atau hingga eksperimenter datang kembali ke ruangan dengan membawa kado yang dipilih (900 detik). Kuesioner delay of gratification adalah instrumen yang digunakan untuk mengukur kemampuan delay of gratification pada domain makanan, physical pleasure, dan interaksi sosial yang diisi oleh ibu. Kuesioner ini telah dilakukan uji validitas konstruk.

Metode analisis data menggunakan NBC. Istilah yang lebih deskriptif untuk metode NBC adalah Independent Feature Model (Bhargavi \& Jyothi, 2009). Metode NBC mengasumsikan ada atau tidak adanya fitur articular dari suatu klasifikasi tidak terkait dengan ada atau tidaknya fitur lain (Bhargavi \& Jyothi, 2009; Ren et al., 2009). NBC berasumsi bahwa semua sifat secara terpisah berkontribusi pada probabilitas. Pada 
teori probabilitas, teorema Bayes menghubungkan probabilitas kondisional dan marginal dari dua kejadian acak (Ren et al., 2009). Artinya, NBC dilakukan dengan membagi dua data yang dimiliki menjadi data training dan data testing (Ren et al., 2009; Bhargavi \& Jyothi, 2009; Karandikar et al., 2015). Data training digunakan untuk membuat model Nä̈ve Bayes dan data testing digunakan untuk menguji model Naïve Bayes tersebut. Prediksi Bayes didasarkan pada teorema Bayes dengan rumus umum (Karandikar, McLeay, Turner, \& Schmitz, 2015) sebagai berikut:

$$
\mathrm{P}(\mathrm{A} \mid \mathrm{B})=\frac{\mathrm{P}(\mathrm{B} \mid \mathrm{A}) \mathrm{P}(\mathrm{A})}{\mathrm{P}(\mathrm{B})}
$$

\begin{tabular}{|c|c|c|}
\hline \multicolumn{3}{|c|}{ Keterangan: } \\
\hline $\mathrm{P}(\mathrm{A} \mid \mathrm{B})$ & & $\begin{array}{l}\text { Probabilitas hipotesis benar untuk data } \\
\text { sampel B yang diamati. }\end{array}$ \\
\hline $\mathrm{P}(\mathrm{B} \mid \mathrm{A})$ & : & $\begin{array}{l}\text { Probabilitas data sampel B, bila } \\
\text { diasumsikan hipotesis benar }\end{array}$ \\
\hline $\mathrm{P}(\mathrm{A})$ & : & Probabilitas data sampel yang diamati \\
\hline $\mathrm{P}(\mathrm{B})$ & : & Probabilitas hipotesis B \\
\hline
\end{tabular}

$\mathrm{B}$ adalah sampel dengan klasifikasi yang tidak diketahui, sedangkan A adalah hipotesis bahwa B adalah data dengan klasifikasi. Pada penelitian ini, klasifikasinya adalah delayer dan non-delayer. Berdasarkan perhitungan menggunakan rumus dari Bayes tersebut, dapat dibuat klasifikasi kemampuan delay of gratification domain makanan, physical pleasure, dan interaksi sosial, serta saat menjalankan tugas delay, baik pada data training maupun data testing. Langkah selanjutnya adalah membandingkan klasifikasi dari waiting time saat melakukan tugas delay dengan kemampuan delay of gratification domain makanan, physical pleasure, dan interaksi sosial. Perhitungan tingkat akurasi, sensitivitas, dan spesifisitas menggunakan rumus (Nurjanto, Savitri, \& Putri, 2014) sebagai berikut:

$$
\begin{aligned}
& \text { Sensitivitas }=\frac{a}{a+c} \\
& \text { Spesifisitas }=\frac{d}{b+d} \\
& \text { Akurasi }=\frac{a+d}{a+b+c+d}
\end{aligned}
$$

Keterangan

a : jumlah partisipan yang terklasifikasi delayer pada waiting time dari tugas delay dan terklasifikasi delayer pada delay of gratification domain makanan, physical pleasure, dan interaksi sosial (sesuai)

b : jumlah partisipan yang terklasifikasi delayer pada waiting time dari tugas delay namun terklasifikasi non-delayer pada delay of gratification domain makanan, physical pleasure, dan interaksi sosial (tidak sesuai)

C : jumlah partisipan yang terklasifikasi non-delayer pada waiting time dari tugas delay namun terklasifikasi delayer pada delay of gratification domain makanan, physical pleasure, dan interaksi sosial (tidak sesuai)

$\mathrm{d}$ : jumlah partisipan yang terklasifikasi non-delayer pada waiting time dari tugas delay dan terklasifikasi non-delayer pada delay of gratification domain makanan, physical pleasure, dan interaksi sosial (sesuai) 


\section{HASIL DAN PEMBAHASAN}

Partisipan penelitian ini berjumlah 28 anak dengan DS, yang memiliki usia kronologis 85 bulan (7 tahun 1 bulan) hingga 168 bulan (14 tahun) $(\mathrm{M}=126,71, \mathrm{SD}=22,56)$, dan usia mental 25 bulan hingga 58 bulan, $(\mathrm{M}=43,14, \mathrm{SD}=9,59)$. Hasil analisis menunjukkan waiting time anak dengan $\mathrm{DS}$ terentang dari 1 hingga 900 detik $(\mathrm{M}=122,71, \mathrm{SD}=239,27)$. Gambar 1 memperlihatkan data waiting time anak dengan DS.

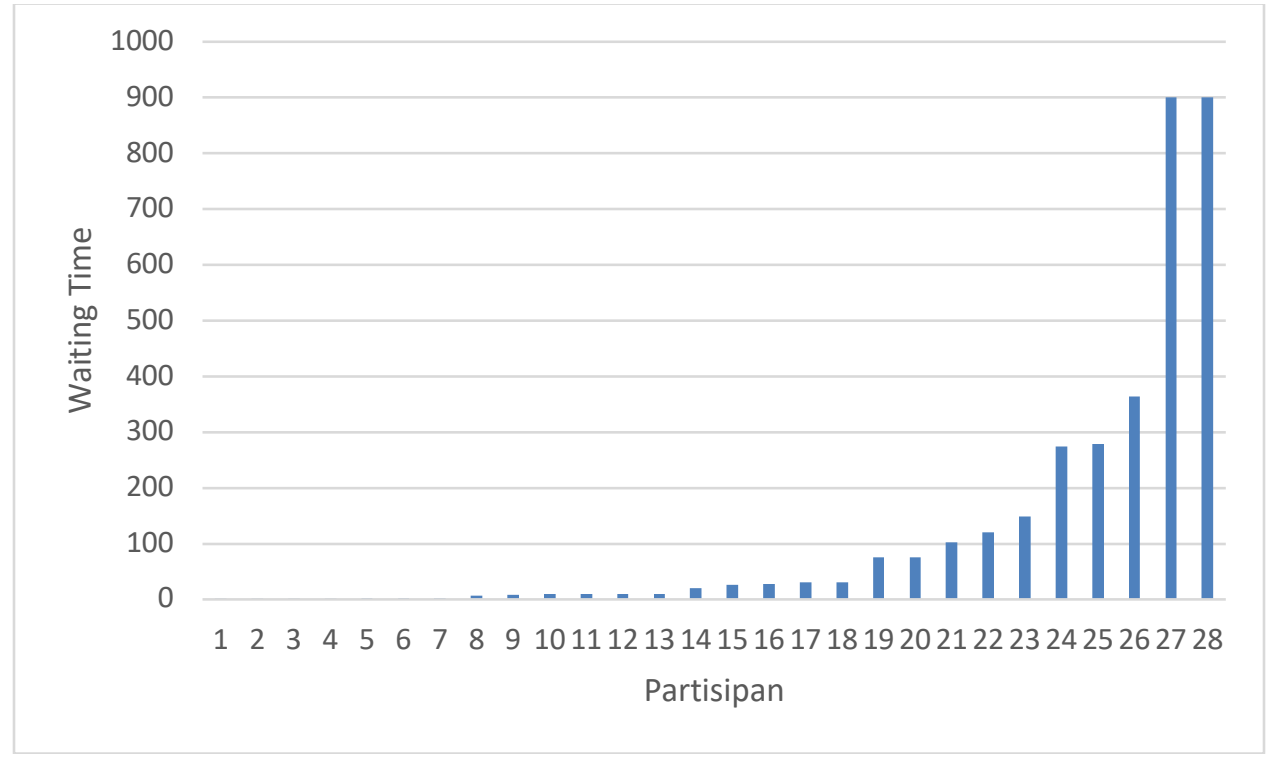

Grafik 1. Data waiting time anak dengan DS saat menjalankan tugas delay

Gambar 1 memperlihatkan sebagian besar anak dengan DS memiliki waiting time yang rendah. Hal ini sejalan dengan penelitian Kopp (1990), Gilmore et al. (2003), dan Cuskelly et al. (2003; 2016). Pada penelitian ini, hanya 2 dari 28 orang yang dapat menunda hingga 900 detik. Penemuan ini pun sejalan dengan temuan Cuskelly et al. (2016) yang menunjukkan hanya 4 dari 22 anak dengan DS yang dapat menjalankan tugas hingga tuntas, yaitu selama 900 detik.

Waiting time dalam penelitian ini sangatlah bervariasi dengan rentang nilai yang sangat jauh, oleh karena itu perlu ditentukan nilai ambang (threshold) untuk mengklasifikasikan setiap hasil observasi ke dalam kategori delayer atau non-delayer. Pada Gambar 1, terlihat bahwa grafik mulai naik setelah nilai waiting time mencapai 100 detik, sehingga pada penelitian ini ditentukan nilai ambangnya adalah 100 detik, dengan ketentuan $\geq 100$ detik diklasifikasikan delayer dan $<100$ detik diklasifikasikan non-delayer.

Prosedur penggunaan metode NBC diawali dengan menentukan $75 \%$ data training dan $25 \%$ data testing dari total data yang dimiliki, yang dilakukan secara acak. Penelitian ini memiliki jumlah sampel penelitian sebanyak 28 orang sehingga data yang digunakan untuk data training sebanyak 21 orang dan 7 orang untuk data testing. Tabel 2 memperlihatkan hasil perhitungan statistik tentang peluang waiting time dalam memprediksi kemampuan delay of gratification domain makanan.

Tabel 2. Hasil Prediksi Peluang Domain Makanan

\begin{tabular}{|c|c|c|c|c|c|}
\hline \multirow[t]{2}{*}{ Responden } & \multirow{2}{*}{$\begin{array}{l}\text { Klasifikasi } \\
\text { waiting time }\end{array}$} & \multicolumn{3}{|c|}{ Prediksi Peluang } & \multirow[t]{2}{*}{ Kesimpulan } \\
\hline & & ND & $\mathrm{D}$ & Klasifikasi & \\
\hline \multicolumn{6}{|c|}{ Data Training } \\
\hline P-1 & $\mathrm{D}$ & 0,008 & 0,992 & $\mathrm{D}$ & Sesuai \\
\hline
\end{tabular}


Neneng Tati Sumiati, Frieda Mangunsong, Guritnaningsih | 73

Pendekatan Metode Naïve Bayes Classifier untuk Memprediksi Kemampuan Delay of Gratification Anak dengan Down Syndrome

\begin{tabular}{|c|c|c|c|c|c|}
\hline \multirow[t]{2}{*}{ Responden } & \multirow{2}{*}{$\begin{array}{c}\text { Klasifikasi } \\
\text { waiting time }\end{array}$} & \multicolumn{3}{|c|}{ Prediksi Peluang } & \multirow[t]{2}{*}{ Kesimpulan } \\
\hline & & ND & $\mathrm{D}$ & Klasifikasi & \\
\hline $\mathrm{P}-4$ & ND & 0,978 & 0,022 & ND & Sesuai \\
\hline P-5 & ND & 0,998 & 0,002 & ND & Sesuai \\
\hline P-6 & $\mathrm{D}$ & 0,040 & 0,960 & D & Sesuai \\
\hline P-7 & ND & 0,997 & 0,002 & ND & Sesuai \\
\hline P-9 & ND & 0,978 & 0,022 & ND & Sesuai \\
\hline P-10 & ND & 0,989 & 0,011 & ND & Sesuai \\
\hline P-11 & ND & 0,999 & 0,001 & ND & Sesuai \\
\hline P-14 & ND & 0,999 & 0,001 & ND & Sesuai \\
\hline P-16 & ND & 0,978 & 0,022 & ND & Sesuai \\
\hline P-17 & ND & 0,998 & 0,002 & ND & Sesuai \\
\hline P-18 & $\mathrm{D}$ & 0,004 & 0,996 & $\mathrm{D}$ & Sesuai \\
\hline P-19 & ND & 0,989 & 0,011 & ND & Sesuai \\
\hline P-20 & ND & 0,999 & 0,001 & ND & Sesuai \\
\hline P-21 & ND & 0,999 & 0,001 & ND & Sesuai \\
\hline P-22 & ND & 0,999 & 0,001 & ND & Sesuai \\
\hline P-23 & D & 0,035 & 0,965 & $\mathrm{D}$ & Sesuai \\
\hline P-24 & $\mathrm{D}$ & 0,004 & 0,996 & $\mathrm{D}$ & Sesuai \\
\hline P-25 & D & 0,008 & 0,992 & $\mathrm{D}$ & Sesuai \\
\hline P-26 & ND & 0,998 & 0,002 & ND & Sesuai \\
\hline P-27 & ND & 0,978 & 0,022 & ND & Sesuai \\
\hline \multicolumn{6}{|c|}{ Data Testing } \\
\hline P-2 & ND & 0,998 & 0,002 & ND & Sesuai \\
\hline P-3 & $\mathrm{D}$ & 0,999 & 0,002 & ND & Tidak Sesuai \\
\hline P-8 & $\mathrm{D}$ & 0,008 & 0,992 & $\mathrm{D}$ & Sesuai \\
\hline P-12 & ND & 0,035 & 0,965 & $\mathrm{D}$ & Tidak Sesuai \\
\hline P-13 & ND & 0,999 & 0,001 & ND & Sesuai \\
\hline P-15 & ND & 0,978 & 0,022 & ND & Sesuai \\
\hline P-28 & ND & 0,978 & 0,022 & ND & Sesuai \\
\hline
\end{tabular}

Keterangan

D: Delayer; ND: Non-delayer

Pada Tabel 2, data training untuk domain makanan memperlihatkan klasifikasi kemampuan delay of gratification yang berasal dari data tugas delay memiliki klasifikasi yang sama atau sesuai dengan klasifikasi kemampuan delay of gratification untuk seluruh partisipan. Pada data testing, terlihat bahwa 5 dari 7 orang memiliki klasifikasi kemampuan waiting time pada saat menjalankan tugas delay yang sesuai dengan klasifikasi kemampuan delay of gratification pada domain makanan. Sebanyak 2 dari 7 orang memiliki klasifikasi kemampuan delay of gratification pada tugas delay yang tidak sesuai dengan klasifikasi kemampuan delay of gratification pada domain makanan. Data testing memperlihatkan bahwa terdapat 5 anak dengan DS yang menunjukkan kemampuan delay of gratification yang terklasifikasi non-delayer pada tugas delay. 4 dari 5 orang tersebut terklasifikasi non-delayer pada domain makanan dan 1 orang terklasifikasi delayer. Sebanyak 2 orang anak dengan DS terklasifikasi delayer pada tugas delay, namun yang terklasifikasi delayer pada domain makanan hanya 1 orang. Hal ini menunjukkan bahwa meskipun pada data training seluruh partisipan memiliki klasifikasi kemampuan delay of gratification yang sama, pada data testing waiting time terdapat peluang yang berbeda dalam memprediksi kemampuan delay of gratification domain makanan.

Tabel 3 memperlihatkan hasil perhitungan statistik tentang peluang waiting time dalam memprediksi kemampuan delay of gratification pada domain physical pleasure.

Tabel 3. Hasil Prediksi Peluang Domain Physical Pleasure

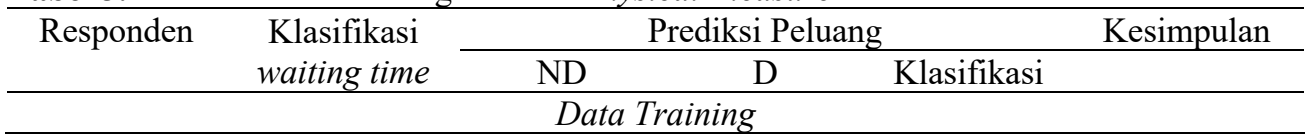




\begin{tabular}{|c|c|c|c|c|c|}
\hline \multirow[t]{2}{*}{ Responden } & \multirow{2}{*}{$\begin{array}{c}\text { Klasifikasi } \\
\text { waiting time }\end{array}$} & \multicolumn{3}{|c|}{ Prediksi Peluang } & \multirow[t]{2}{*}{ Kesimpulan } \\
\hline & & ND & $\mathrm{D}$ & Klasifikasi & \\
\hline P-1 & $\mathrm{D}$ & 0.075 & 0.925 & $\mathrm{D}$ & Sesuai \\
\hline P-4 & ND & 0.999 & 0.001 & ND & Sesuai \\
\hline P-5 & ND & 0.999 & 0.001 & ND & Sesuai \\
\hline P-6 & $\mathrm{D}$ & 0.014 & 0.986 & $\mathrm{D}$ & Sesuai \\
\hline P-7 & ND & 0.999 & 0.001 & ND & Sesuai \\
\hline P-9 & ND & 0.975 & 0.025 & ND & Sesuai \\
\hline P-10 & ND & 0.999 & 0.001 & ND & Sesuai \\
\hline P-11 & ND & 1 & 0 & ND & Sesuai \\
\hline P-14 & ND & 1 & 0 & ND & Sesuai \\
\hline P-16 & ND & 0.998 & 0.002 & ND & Sesuai \\
\hline P-17 & ND & 0.950 & 0.050 & ND & Sesuai \\
\hline P-18 & D & 0.002 & 0.998 & $\mathrm{D}$ & Sesuai \\
\hline P-19 & ND & 0.999 & 0.001 & ND & Sesuai \\
\hline P-20 & ND & 0.994 & 0.006 & ND & Sesuai \\
\hline P-21 & ND & 0.999 & 0.001 & ND & Sesuai \\
\hline P-22 & ND & 0.950 & 0.050 & ND & Sesuai \\
\hline P-23 & $\mathrm{D}$ & 0.004 & 0.997 & $\mathrm{D}$ & Sesuai \\
\hline P-24 & D & 0.002 & 0.998 & $\mathrm{D}$ & Sesuai \\
\hline P-25 & D & 0.002 & 0.998 & $\mathrm{D}$ & Sesuai \\
\hline P-26 & ND & 0.991 & 0.009 & ND & Sesuai \\
\hline P-27 & ND & 0.950 & 0.050 & ND & Sesuai \\
\hline \multicolumn{6}{|c|}{ Data Testing } \\
\hline P-2 & ND & 1 & 0 & ND & Sesuai \\
\hline P-3 & $\mathrm{D}$ & 0.991 & 0.009 & ND & Tidak Sesuai \\
\hline P-8 & $\mathrm{D}$ & 0.002 & 0.998 & $\mathrm{D}$ & Sesuai \\
\hline P-12 & ND & 0.038 & 0.962 & $\mathrm{D}$ & Tidak Sesuai \\
\hline P-13 & ND & 1 & 0 & ND & Sesuai \\
\hline P-15 & ND & 0.950 & 0.050 & ND & Sesuai \\
\hline P-28 & ND & 0.950 & 0.050 & ND & Sesuai \\
\hline
\end{tabular}

Keterangan

D: Delayer; ND: Non-delayer

Berdasarkan Tabel 3, data training untuk domain physical pleasure memperlihatkan klasifikasi kemampuan delay of gratification yang berasal dari data tugas delay pada seluruh partisipan memiliki klasifikasi yang sama atau sesuai dengan klasifikasi kemampuan delay of gratification dari data domain physical pleasure. Pada data testing, terlihat bahwa 5 dari 7 orang memiliki klasifikasi kemampuan waiting time pada saat menjalankan tugas delay yang sesuai dengan klasifikasi kemampuan delay of gratification pada domain physical pleasure. Sebanyak 2 dari 7 orang memiliki klasifikasi kemampuan delay of gratification pada tugas delay yang tidak sesuai dengan klasifikasi kemampuan delay of gratification domain makanan. Data testing memperlihatkan bahwa terdapat 5 orang anak dengan DS yang terklasifikasi non-delayer pada waiting time, namun hanya 4 orang yang terklasifikasi non-delayer pada domain physical pleasure. Temuan ini menunjukkan bahwa terdapat perbedaan pada peluang waiting time dalam memprediksi kemampuan delay of gratification domain physical pleasure pada data training dan data testing.

Tabel 4 memperlihatkan hasil perhitungan statistik tentang peluang waiting time dalam memprediksi kemampuan delay of gratification domain interaksi sosial.

Tabel 4. Hasil Prediksi Peluang Domain Interaksi Sosial

\begin{tabular}{cccccc}
\hline Responden & Klasifikasi & \multicolumn{3}{c}{ Prediksi Peluang } & Kesimpulan \\
\cline { 3 - 4 } & waiting time & ND & D & Klasifikasi & \\
\hline P-1 & & \multicolumn{2}{c}{ Data Training } & \\
\hline
\end{tabular}


Neneng Tati Sumiati, Frieda Mangunsong, Guritnaningsih | 75 Pendekatan Metode Naïve Bayes Classifier untuk Memprediksi Kemampuan Delay of Gratification Anak dengan Down Syndrome

\begin{tabular}{|c|c|c|c|c|c|}
\hline P-4 & ND & 0.978 & 0.022 & ND & Sesuai \\
\hline P-5 & ND & 0.998 & 0.002 & ND & Sesuai \\
\hline P-6 & $\mathrm{D}$ & 0.040 & 0.960 & $\mathrm{D}$ & Sesuai \\
\hline P-7 & ND & 0.997 & 0.002 & ND & Sesuai \\
\hline P-9 & ND & 0.978 & 0.022 & ND & Sesuai \\
\hline P-10 & ND & 0.989 & 0.011 & ND & Sesuai \\
\hline P-11 & ND & 0.999 & 0.001 & ND & Sesuai \\
\hline P-14 & ND & 0.999 & 0.001 & ND & Sesuai \\
\hline P-16 & ND & 0.978 & 0.022 & ND & Sesuai \\
\hline P-17 & ND & 0.998 & 0.002 & ND & Sesuai \\
\hline P-18 & $\mathrm{D}$ & 0.004 & 0.996 & $\mathrm{D}$ & Sesuai \\
\hline P-19 & ND & 0.989 & 0.011 & ND & Sesuai \\
\hline P-20 & ND & 0.999 & 0.001 & ND & Sesuai \\
\hline P-21 & ND & 0.999 & 0.001 & ND & Sesuai \\
\hline P-22 & ND & 0.999 & 0.001 & ND & Sesuai \\
\hline P-23 & $\mathrm{D}$ & 0.035 & 0.965 & $\mathrm{D}$ & Sesuai \\
\hline P-24 & D & 0.004 & 0.996 & D & Sesuai \\
\hline P-25 & $\mathrm{D}$ & 0.008 & 0.992 & D & Sesuai \\
\hline P-26 & ND & 0.998 & 0.002 & ND & Sesuai \\
\hline P-27 & ND & 0.978 & 0.022 & $\mathrm{ND}$ & Sesuai \\
\hline \multicolumn{6}{|c|}{ Data Testing } \\
\hline $\mathrm{P}-2$ & ND & 0.998 & 0.002 & ND & Sesuai \\
\hline P-3 & $\mathrm{D}$ & 0.999 & 0.002 & ND & Tidak \\
\hline P-8 & $\mathrm{D}$ & 0.951 & 0.049 & ND & Tidak \\
\hline P-12 & ND & 0.951 & 0.049 & ND & Sesuai \\
\hline P-13 & ND & 0.999 & 0.001 & ND & Sesuai \\
\hline P-15 & ND & 0.999 & 0.001 & ND & Sesuai \\
\hline P-28 & ND & 0.973 & 0.027 & ND & Sesuai \\
\hline
\end{tabular}

Keterangan

D: Delayer; ND: Non-delayer

Berdasarkan Tabel 4, data training menunjukkan bahwa kemampuan waiting time saat menjalankan tugas delay dapat memprediksi kemampuan delay of gratification pada domain interaksi sosial dengan tepat. Namun, data testing memperlihatkan bahwa 5 dari 7 orang memiliki kemampuan waiting time pada saat menjalankan tugas delay yang sesuai dengan klasifikasi kemampuan delay of gratification pada domain interaksi sosial. Pada data testing, terlihat bahwa anak dengan DS yang terklasifikasi non-delayer pada tugas delay sebanyak 5 orang dan semuanya terklasifikasi non-delayer pada domain interaksi sosial. Terdapat 2 orang partisipan yang terklasifikasi delayer pada tugas delay, namun pada domain interaksi sosial kedua partisipan tersebut terklasifikasi non-delayer.

Perhitungan tingkat akurasi, sensitivitas, dan spesifisitas berdasarkan hasil perhitungan statistik yang tertera pada Tabel 2, Tabel 3 dan Tabel 4 dapat dilihat pada Tabel 5.

Tabel 5. Tingkat Akurasi, Sensitivitas, dan Spesifisitas

\begin{tabular}{lccccccc}
\hline \multirow{2}{*}{ Domain } & \multicolumn{9}{c}{ Klasifikasi } & Akurasi & Sensitivitas & Spesifisitas \\
\cline { 2 - 5 } & \multicolumn{3}{c}{ Sesuai } & & & \\
\cline { 2 - 5 } Data Training & A & D & B & C & & \\
M & 6 & 15 & 0 & 0 & $100 \%$ & $100 \%$ & $100 \%$ \\
PP & 6 & 15 & 0 & 0 & $100 \%$ & $100 \%$ & $100 \%$ \\
IS & 6 & 15 & 0 & 0 & $100 \%$ & $100 \%$ & $100 \%$ \\
Data Testing & & & & & & & \\
M & 1 & 4 & 1 & 1 & $71.43 \%$ & $80 \%$ & $50 \%$ \\
PP & 1 & 4 & 1 & 1 & $71.43 \%$ & $80 \%$ & $50 \%$
\end{tabular}




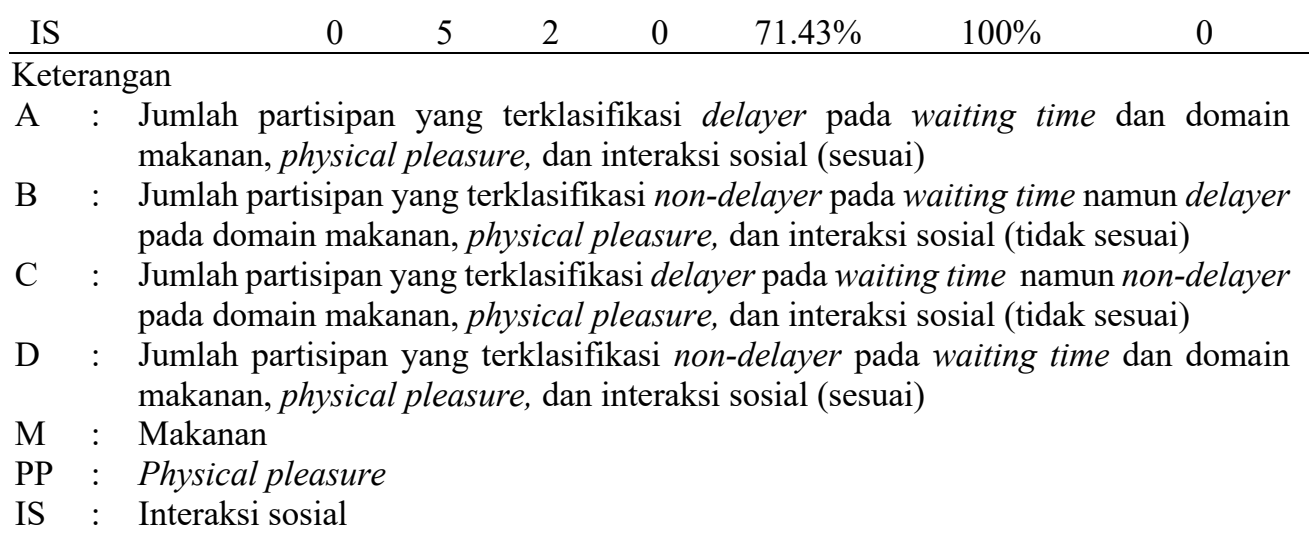

Berdasarkan Tabel 5, data training kemampuan delay of gratification yang diperoleh dari tugas delay dan kuesioner untuk domain makanan, physical pleasure, dan interaksi sosial memiliki tingkat akurasi, sensitivitas, dan spesifisitas yang sangat tepat, yaitu 100\%. Seluruh partisipan dengan kemampuan delay of gratification yang terklasifikasi delayer dan non-delayer pada tugas delay memiliki klasifikasi yang sama pada kuesioner delay of gratification baik pada domain makanan, physical pleasure, maupun interaksi sosial. Hal ini mencerminkan model yang dibuat sangat bagus karena dapat melakukan prediksi dengan tepat.

Pengujian terhadap model yang dibuat, yaitu dengan menggunakan data testing, menunjukkan bahwa tugas delay yang terukur melalui waiting time dapat memprediksi kemampuan delay of gratification yang diukur melalui kuesioner untuk domain makanan, physical pleasure, dan interaksi sosial sebesar 71,43\% (lihat Tabel 5). Hal ini menunjukkan bahwa tugas delay cukup akurat memprediksi kemampuan delay of gratification baik domain makanan, physical pleasure, maupun interaksi sosial. Temuan yang diperoleh berbeda dengan hasil penelitian Kopp (1990) yang menunjukkan bahwa tidak terdapat korelasi antara kemampuan delay of gratification pada dua tugas delay yang diberikan. Pada penelitian Cuskelly et al. (2003) terkait kemampuan delay of gratification pada anak dengan DS, hanya terdapat korelasi pada dua tugas delay yang berupa otherdirected. Sementara itu, pada tugas delay yang berupa self-imposed dan other-directed tidak ditemukan adanya korelasi. Temuan penelitian ini menunjukkan bahwa tugas delay yang bersifat self-imposed cukup akurat dalam memprediksi kemampuan delay of gratification pada domain makanan, physical pleasure, dan interaksi sosial. Hal ini pun sejalan dengan penelitian Cuskelly et al. (2001) yang menunjukkan bahwa terdapat korelasi antara kemampuan delay of gratification saat menjalankan tugas delay pada waktu yang berbeda. Temuan ini juga memperkuat hasil penelitian Cuskelly et al. (2001) bahwa kemampuan delay of gratification anak dengan DS dalam menunda keinginannya saat menjalankan tugas delay dapat memprediksi kemampuan delay of gratification pada domain makanan, physical pleasure, dan interaksi sosial.

Tingkat sensitivitas diperlukan untuk memprediksi anak dengan DS yang tidak dapat menunda gratifikasi (non-delayer). Pada data testing, tingkat sensitivitas untuk domain makanan dan physical pleasure adalah sebesar $80 \%$, sedangkan untuk domain interaksi sosial sebesar 100\% (lihat Tabel 5). Temuan pada penelitian ini menunjukkan bahwa anak dengan DS yang terklasifikasi non-delayer pada tugas delay dapat diprediksi non-delayer pula pada domain makanan, physical pleasure, dan interaksi sosial dengan tingkat yang tergolong tinggi.

Tingkat sensitivitas yang tinggi disebabkan oleh banyaknya partisipan yang terklasifikasi non-delayer dan terbukti non-delayer. Pada penelitian ini, partisipan yang terklasifikasi non-delayer, baik pada tugas delay maupun kuesioner, lebih banyak dibandingkan partisipan yang terklasifikasi delayer. Hal ini sejalan dengan penelitian sebelumnya yang menunjukkan bahwa kemampuan delay of gratification anak dengan DS rendah (Kopp, 1990; Cuskelly et al., 2001; 2003; 2016). Dengan kata lain, anak dengan DS kurang mampu menunda gratifikasi atau non-delayer baik pada domain makanan, physical pleasure, interaksi sosial, maupun pada saat menjalankan tugas delay.

Rendahnya kemampuan delay of gratification pada anak dengan DS diduga karena perkembangan tersebut berkembang lebih lambat dibandingkan dengan usia mentalnya (Cuskelly et al., 2003). Oleh karena 
Neneng Tati Sumiati, Frieda Mangunsong, Guritnaningsih | 77

Pendekatan Metode Naïve Bayes Classifier untuk Memprediksi Kemampuan Delay of Gratification Anak dengan Down Syndrome

itu, sebagian besar anak DS terklasifikasi non-delayer. Mereka mengalami kesulitan untuk menunda kepuasan baik pada tugas delay, maupun kemampuan delay of gratification pada domain makanan, physical pleasure, dan interaksi sosial. Hal ini diduga menjadi faktor yang membuat instrumen pengukuran delay of gratification, baik berupa tugas delay maupun kuesioner, memiliki sensitivitas yang tinggi dalam mendeteksi anak dengan DS yang terklasifikasi non-delayer.

Tingkat spesifisitas diperlukan untuk memprediksi anak dengan DS yang mampu menunda gratifikasi (delayer). Adapun tingkat spesifisitas untuk domain makanan dan physical pleasure adalah sebesar 50\%, sedangkan interaksi sosial tidak memiliki nilai spesifisitas (lihat Tabel 5). Hal ini menunjukkan bahwa tugas delay memiliki spesifisitas yang rendah untuk memprediksi kemampuan delay of gratification, terutama untuk domain interaksi sosial. Maknanya, tugas delay dinilai kurang efektif dalam memprediksi anak dengan DS yang terklasifikasi delayer karena anak dengan DS yang terklasifikasi delayer dan terbukti delayer hanya berjumlah sedikit. Hal ini pun sejalan dengan hasil penelitian Cuskelly et al. (2001) di mana hanya terdapat $35 \%$ partisipan yang dapat menunggu hingga 900 detik dan pada penelitian Cuskelly et al. (2003) yang hanya terdapat $20 \%$ anak dengan DS yang terklasifikasi delayer.

Hasil penelitian ini menunjukkan bahwa tidak terdapat nilai spesifisitas pada domain interaksi sosial. Temuan ini diduga ada hubungannya dengan karakteristik dari anak dengan DS. Menurut Kasari \& Freeman (2001), anak dengan DS memiliki ketertarikan untuk berinteraksi sosial. Minat yang besar untuk melakukan aktivitas bersama orang lain membuatnya sulit menunda keinginannya tersebut. Anak dengan DS memiliki motivasi sosial yang besar (Grieco et al., 2015) sehingga kehadiran orang lain menjadi suatu bentuk distraksi. Mereka mengalihkan perhatiannya pada orang lain yang berada di sekitarnya dan mengabaikan tugas yang harus diselesaikannya. Hal ini diduga menjadi penyebab mereka mengalami kesulitan untuk menunda kepuasan (delayer) pada domain interaksi sosial.

Temuan pada penelitian ini menunjukkan bahwa tingkat sensitivitas tergolong tinggi dan spesifisitas tergolong rendah. Secara umum, apabila tingkat sensitivitas tinggi, tingkat spesifisitas akan rendah. Hal ini dikarenakan sensitivitas dan spesifisitas diperoleh dari jumlah partisipan yang terklasifikasi delayer dan nondelayer. Oleh karena itu, apabila terdapat banyak partisipan yang terklasifikasi non-delayer, partisipan yang terklasifikasi delayer pun berjumlah sedikit. Pada penelitian ini, diketahui bahwa tingkat spesifisitas rendah karena partisipan yang terklasifikasi delayer sedikit.

Hasil penelitian ini menunjukkan bahwa tugas delay memiliki akurasi yang cukup baik dalam memprediksi kemampuan delay of gratification anak dengan DS pada domain makanan, physical pleasure, dan interaksi sosial. Implikasinya adalah pengukuran kemampuan delay of gratification anak dengan DS dapat dilakukan, baik dengan menggunakan tugas delay maupun kuesioner yang diisi ibu. Adapun sensitivitasnya tergolong tinggi, namun spesifisitas tergolong rendah terutama untuk domain interaksi sosial. Hal ini menunjukkan bahwa kesulitan anak dengan DS dalam menunda kepuasan dapat terungkap baik melalui tugas delay maupun pengamatan ibu. Implikasinya, orang tua dapat mengamati kesulitan anak dengan DS dalam menunda kepuasan pada beberapa domain seperti domain makanan, physical pleasure, dan interaksi sosial. Hasil pengamatan dapat digunakan untuk mengoptimalkan kemampuan delay of gratification anak dengan DS.

Keterbatasan dalam penelitian ini adalah jumlah partisipan yang tergolong kecil sehingga diperlukan kehati-hatian dalam menginterpretasikan hasil analisis. Penelitian selanjutnya dapat dilakukan pada partisipan yang lebih banyak dan memperluas fokus penelitian, seperti menambah variabel penelitian yang diduga memiliki pengaruh pada kemampuan delay of gratification anak dengan DS, misalnya diberikan tugas delay tanpa dan dengan kehadiran orang lain.

\section{SIMPULAN}

Kemampuan delay of gratification anak dengan DS yang diukur berdasarkan waiting time saat menjalankan tugas delay dapat memprediksi kemampuan delay of gratification domain makanan, physical pleasure, dan interaksi sosial berdasarkan persepsi ibu, dengan tingkat akurasinya sebesar 71,43\%. Adapun tingkat sensitivitas tergolong tinggi, sementara tingkat spesifisitas tergolong rendah. Hal ini dikarenakan anak 
Neneng Tati Sumiati, Frieda Mangunsong, Guritnaningsih |

Pendekatan Metode Naïve Bayes Classifier untuk Memprediksi Kemampuan Delay of Gratification

Anak dengan Down Syndrome

dengan DS memiliki kemampuan delay of gratification yang rendah sehingga sebagian besar anak dengan DS terklasifikasi non-delayer. Mereka mengalami kesulitan dalam menunda kepuasan, terutama pada domain interaksi sosial. Implikasi temuan ini adalah kemampuan delay of gratification dapat diukur, baik menggunakan tugas delay maupun kuesioner berdasarkan hasil pengamatan orang tua. Anak dengan DS yang terklasifikasi non-delayer dapat terukur dengan tepat sehingga dapat memudahkan orang tua, guru, ataupun terapis untuk membuat program yang dapat mengoptimalkan kemampuan mereka. Temuan lainnya adalah anak dengan DS tampak mengalami kesulitan yang lebih besar saat harus menunda kepuasan pada domain interaksi sosial.

\section{DAFTAR PUSTAKA}

Bhargavi, P., \& Jyothi, S. (2009). Applying Naïve Bayes data mining technique for classification of agricultural land soils. International Journal of Computer Science and Network Security, 9(8), 117-122.

Borella, E., Carretti, B., \& Lanfranchi, S. (2013). Inhibitory mechanisms in Down syndrome: Is there a specific or general deficit? Research in Developmental Disabilities, 34(1), 65-71.

Brunamonti, E., Pani, P., Papazachariadis, O., Onorati, P., Albertini, G., \& Ferraina, S. (2011). Cognitive control of movement in Down syndrome. Research in Developmental Disabilities, 32(5), 1792-1797.

Carney, D. P. J., Henry, L. A., Messer, D. J., Danielsson, H., Brown, J. H., \& Rosenberg, J. (2013). Using developmental trajectories to examine verbal and visuospatial short-term memory development in children and adolescents with Williams and Down syndromes. Research in Developmental Disabilities, 34(10), 3421-3432.

Costanzo, F., Varuzza, C., Menghini, D., Addona, F., Gianesini, T., \& Vicari, S. (2013). Executive functions in intellectual disabilities: A comparison between Williams syndrome and Down syndrome. Research in Developmental Disabilities, 34(5), 1770-1780.

Cuskelly, M., Einam, M., \& Jobling, A. (2001). Delay of gratification in young adults with Down syndrome. Down Syndrome Research and Practice, 7(2), 60-67.

Cuskelly, M., Gilmore, L., Glenn, S., \& Jobling, A. (2016). Delay of gratification: A comparison study of children with Down syndrome, moderate intellectual disability and typical development, Journal of Intellectual Disability Research, 60(9), 865-873.

Cuskelly, M., Zhang, A., \& Gilmore, L. (1998). The importance of self-regulation in young children with down syndrome. International Journal of Disability, Development and Education, 45(3), 331-341.

Cuskelly, M., Zhang, A., \& Hayes, A. (2003). A mental age-matched comparison study of delay of gratification in children with Down syndrome. International Journal of Disability, Development and Eduction, 50(3), 239-251.

Dansereau, D. F., Knight, D. K., \& Flynn, P. M. (2013). Improving adolescent judgement and decision making. Professional Psychology: Research and Practice, 44(4), 274-282.

Dykens, E., Schwenk, M., Maxwell, M., \& Myatt, B. (2007). The Sentence Completion and Three Wishes tasks: Windows into the inner lives of people with intellectual disabilities. Journal of Intellectual Disabilities Research, 51(8), 588-597.

Finestack, L. H., \& Abbeduto, L. (2010). Expressive language profiles of verbally expressive adolescents and young adults with Down syndrome or fragile X syndrome, 53(5).

Gameren-Oosterom, H. B. M. Van, Fekkes, M., Buitendijk, S. E., Mohangoo, A. D., \& Wouwe, J. P. Van. (2011). Development, problem behavior, and quality of life in a population based sample of eight-year-

old children with down syndrome. PLoS ONE 6(7), 16-20.

Gilmore, L., Cuskelly, M., \& Hayes, A. (2003). Self-regulatory behaviors in children with Down syndrome and typically developing children measured using the Goodman Lock Box, Research in Developmental Disabilities, 24(2), 95-108.

Gravetter, F. J., \& Forzano, Lori-Ann B. (2018). Research methods for behavioral sciences (6th ed.). Cengage Learning: US. 
Neneng Tati Sumiati, Frieda Mangunsong, Guritnaningsih | 79

Pendekatan Metode Naïve Bayes Classifier untuk Memprediksi Kemampuan Delay of Gratification Anak dengan Down Syndrome

Grieco, J., Pulsifer, M., Seligsohn, K., Skotko, B., \& Schwartz, A. (2015). Down syndrome: Cognitive and behavioral functioning across the lifespan, 149(2), 135-149.

Ho, S., Tong, E. M. W., \& Jia, L. (2016). Authentic and hubristic pride: Differential effects on delay of gratification, 16(8), 1147-1156.

Hoerger, M., Quirk, S. W., \& Weed, N. C. (2011). Development and validation of the Delaying Gratification Inventory. Psychological Assessment, 23(3), 725-738.

Karandikar, J., McLeay, T., Turner, S., \& Schmitz, T. (2015). Tool wear monitoring using Naïve Bayes classifiers. The International Journal of Advanced Manufacturing Technology, 77, 1613-1626.

Kasari, C., \& Freeman, S.F.N. (2001). Task-related sosial behavior in children with Down syndrome. American Journal on Mental Retardation, 106(3), 253-264.

Kopp, C. B. (1990). The growth of self-monitoring among young children with Down syndrome. In Cicchetti, D., \& Beeghly, M., (Eds). Children with Down syndrome: A developmental perspective (pp. 231-251). Cambridge University Press.

Lanfranchi, S., Jerman, O., Dal Pont, E., Alberti, A., \& Vianello, R. (2010). Executive function in adolescents with Down syndrome. Journal of Intellectual Disability Research, 54(4), 308-319.

Liu, X., Wang, L., \& Jiang, J. (2013). Generalizability of delay of gratification: Dimensionality and function. Psychological Reports: Measures \& Statistics, 113(2), 464-485.

Lott, I. T., \& Dierssen, M. (2010). Cognitive deficits and associated neurological complications in individuals with Down's syndrome. The Lancet Neurology, 9(6), 623-633.

Mischel, W. (1974). Processes in delay of gratification. In Advances in experimental social psychology (pp. 249-292).

Mischel, W., Shoda, Y., \& Rodriguez, M. L. (1989). Delay of gratification in children. Science, 244(4907), 933-938.

Muktamar, B. A., Setiawan, N. A., \& Adji, T. B. (2015). Pembobotan korelasi pada Naïve Bayes Classifier. Seminar Nasional Teknologi Informasi Dan Multimedia.

Nurjanto, R.P.B., Savitri, Y. \& Putri, M.C. (2014). Sensitivitas, spesifisitas, dan akurasi pengukuran mental indeks pada radiografi panoramik wanita pascamenopause. Dentomaxillofacial Radiology Dental Journal, 5(1), 8-13.

Pinter, J. D., Eliez, S., Schmitt, J. E., Capone, G. T., \& Reiss, A. L. (2001). Neuroanatomy of Down's syndrome: A high-resolution MRI study. American Journal of Psychiatry, 158(10), 1659-1665.

Ren, J., Lee, S. D., Chen, X., Kao, B., Cheng, R., \& Cheung, D. (2009). Naive Bayes classification of uncertain data. The 9th IEEE International Conference on Data Mining (ICDM), 944-949.

Roubertoux, P. L., \& Kerdelhué , B. (2006). Trisomy 21: From chromosomes to mental retardation, 36(3), $346-355$.

Rowe, J., Lavender, A., \& Turk, V. (2006). Cognitive executive function in Down's syndrome. British Journal of Clinical Psychology, 45(1), 5-17.

Saldaña, D. (2004). Interactive assessment of metacognition: Exploratory study of a procedure for persons with severe mental retardation. European Journal of Psychology of Education, 19(4), 349-364.

Sastre-Riba, S., Fonseca-Pedrero, E., \& Poch-Olivé, M. L. (2015). Early development of executive functions: A differential study, 31(2), 607-614.

Setiawan, A., Astuti, I.F., \& Kridalaksana, A.H. (2015). Klasifikasi dan pencarian buku referensi akademik menggunakan metode Naïve Bayes Classifier (NBC): Studi kasus perpustakaan daerah Provinsi Kalimantan Timur. Informatika Mulawarman: Jurnal Ilmiah Ilmu Komputer, 10(1), 1-10.

Zelazo, P. D. (2015). Executive function: Reflection, iterative reprocessing, complexity, and the developing brain. Developmental Review, 38, 55-68. 